\title{
Iterative Cellular Automation Approach to Analyze Spatial Dynamics of Urbanization and Population Growth
}

\author{
Urooj Saeed $^{1,2 *}$, Sajid Rashid Ahmad ${ }^{1}$ \\ ${ }^{1}$ College of Earth and Environmental Sciences, University of the Punjab Lahore, Pakistan \\ ${ }^{2}$ Urban Sector Planning and Management Services Unit (Pvt.) Limited, Pakistan
}

Received: 21 August 2020

Accepted: 21 December 2020

\begin{abstract}
Population measurement and its spatial distribution are required to understand the urban pattern of any city. We have used a methodology for measuring urban spatial morphology, infill, outlying expansion, and compactness over a decade. The aims of this research are related to data-driven categorization often large cities of Punjab and its correlation with urban attributes by identifying relative disparities in expansion and vertical growths; instead of city portfolios exerted and/or perceived by various groups of relevant urban stakeholders. Urban extents and sprawls were identified by using Geospatial data and techniques by applying supervised parameter optimization. The analytical tool was employed to highlight and better understand the relative (hierarchical) position of selected cities of Punjab, Pakistan. The results depict that the total urban area of selected cities has increased in ten years (2008-2018) from $914 \mathrm{~km}^{2}$ to $1649 \mathrm{~km}^{2}$. The cities' saturation level helped to identify highly densified and the cities where the potential of infill is available. This study provides an effective and efficient way to monitor and evaluate the morphology of the cities and addresses the issues of mismanaged urban sprawl and decreasing densities.
\end{abstract}

Keywords: cities morphology, remote sensing, landscan, population density, sustainable urbanization

\section{Introduction}

Cities are the magnets and engines of urban growth [1], about $44 \mathrm{M}$ (million) people are being added every year to Asian cities, generating the need for more infrastructure [2]. The world has experienced a high population growth rate after the industrial revolution [3], which adds great pressure on resources, the

*e-mail: saeed.urooj@gmail.com environment, and sustainable development [4]. It is estimated that in the urban areas of Pakistan almost 50 million people will be lived between 2014 to 2050. Moreover, the urban sprawl generally includes changes in land use of outer peripheries in an urban area[5]. Population density, urban sprawl, and landuse conversion shall be taken into account to estimate urban patterns [6]. These indicators are key to stipulate the decisions of the governments [7]. To estimate the population, census is the key, but the conventional doorto-door evaluation is costly and also time-consuming [8]. The restraining fact for using population data in the 
urban demographic study in Pakistan is the long-awaited census in Pakistan [9]. The latest population survey took place after two decades in 2017 [10]. The recent studies identified the multi-temporal Landsat satellite images with socio-economic data to observe the urban growth focus on urban sprawl detection and estimating directional changes using Markov algorithm [11]. the population and urban growth patterns could be utilized as baseline for planning and development [12]. Landsat satellite imagery with the help of multivariate statistical analysis are used to map landscape imperviousness indexes [13].

Multispectral images for estimation of population density with the help of statistical measures and regression models are key elements for population estimations $[14,15]$. In recent studies Landsat Thematic Mapper (TM) for image interpolation method [16], night light imagery [17]. [18] are also used to determine urban population density. Satellites are used to observed the earth from an orbit variables [19] and also to produce 30" high-resolution population databases for the globe [20]. Landsat and LandScan proved to be costeffective, time-efficient, and multi-temporal datasets, for identification of patterns by comparing compactness and expansion of the major cities along with population dynamics between 2008 and 2018. In Pakistan, the cities are administrated with demarcation limits such as areas of the metropolitan corporation, municipal corporation, and town committees, or cantonment boards [21]. However, the city administrations do not follow the notified boundaries, of which lack of land use planning is a vital issue that results in expansion beyond their administrative boundaries. Urbanized areas are mostly overcrowded and densely clustered in city centers [22]. In a recent study [23], Lahore metropolitan of Pakistan was selected and observed that the urban growth patterns which highlighted $100 \%$ increase in the urban area from 1999 to 2011. Also, with the help of GIS, the urban expansion and socioeconomic development was analyzed in Bahawalpur, Pakistan and concluded that the population density of the city increased mainly due to the migration of people from rural to the urban areas for better lifestyle [24]. Furthermore, LandScan utilized for modeling approach and its principles for attaining the temporal dynamics of population by evaluating night time and day time population at 3 arc second resolution [25]. Calka and Bielecka, [26] observed that the population of Poland using LandScan dataset and compared its accuracy with the official polish population grid. In another study, urban expansion with the help of change vector analysis (CVA) extracted and analyzed the transformation of barren land, vegetation, and water into urban areas using the temporal segmentation approach [27].

The concepts of population distribution and density are different, as distribution is based on location, while density is a ratio. For equitable urban and rural development of Punjab (most populated province of Pakistan), accurate data on urban expansion, cities' saturation, and the population density trends were missing, and a dire need was felt at various platforms during planning and management. The study circumscribes spatio-temporal urban growth modelling to extrapolate the past and future urban growth patterns and its impact on various land-use classes integration geospatial techniques including cellular automata (CA) [28]. The study focused on the reliability of cellular automata algorithm for extraction of urban growth patterns with best model calibration approach [29]. In this study, an integrated approach has been used to cater to the cross-linkages between both the factors. This study also tracks the vibrant characteristics and spatiotemporal morphology with population distribution across ten major cities of Punjab, for sustainable spatial planning and management of cities.

\section{Study Area}

Punjab is the most populous among the five provinces of Pakistan and covers an area of 205,344 $\mathrm{km}^{2}$ $\left(79,284 \mathrm{mi}^{2}\right)$ with a population of more than 100 million. Moreover, the concentration of the urban population is confined to a few cities in Punjab. The study discusses urban morphology of ten larger cities given in in Fig. 1. Lahore is the provincial capital and also known as 'city of gardens' and Faisalabad is the industrial hub of Punjab. Gujranwala city called the 'city of wrestlers' and also known as rice producer and Sialkot is the hub of small and medium industries and give the highest per capita income in the country. Sahiwal is good in cotton goods manufacturers and woodwork. Sargodha is famous for orange production. Bahawalpur is a city of monuments and forts. Dera Ghazi Khan is the junction for all four provinces of Pakistan. Moreover, Rawalpindi is famous for its landscape and historical monuments. Punjab province climate conditions are diverse and multiple weather conditions such as, foggy winter, summer, spring and monsoon.

\section{Material and Methods}

\section{Data Acquisition and Processing}

The LandScan data was acquired from LandScan ${ }^{\mathrm{TM}}$ for 2008 and 2017 [30], and later it was projected to the year 2018. We acquired Landsat TM and Operational Land Imager (OLI) images (30 $\mathrm{m}$ resolution) from the United States Geological Survey because of excellent price-quality ratio, spectral bands coverage, and spatial characteristics.. The multilayer images were downloaded from the USGS website [31]. Radiometric calibration and correction processes were used for the conversion of digital number (DN) to reflectance, also baptized as the top of atmospheric correction [32]. The change in brightness values denotes the rate of change in the surface condition of the area of interest [33]. The subsets of all satellite images were produced using 


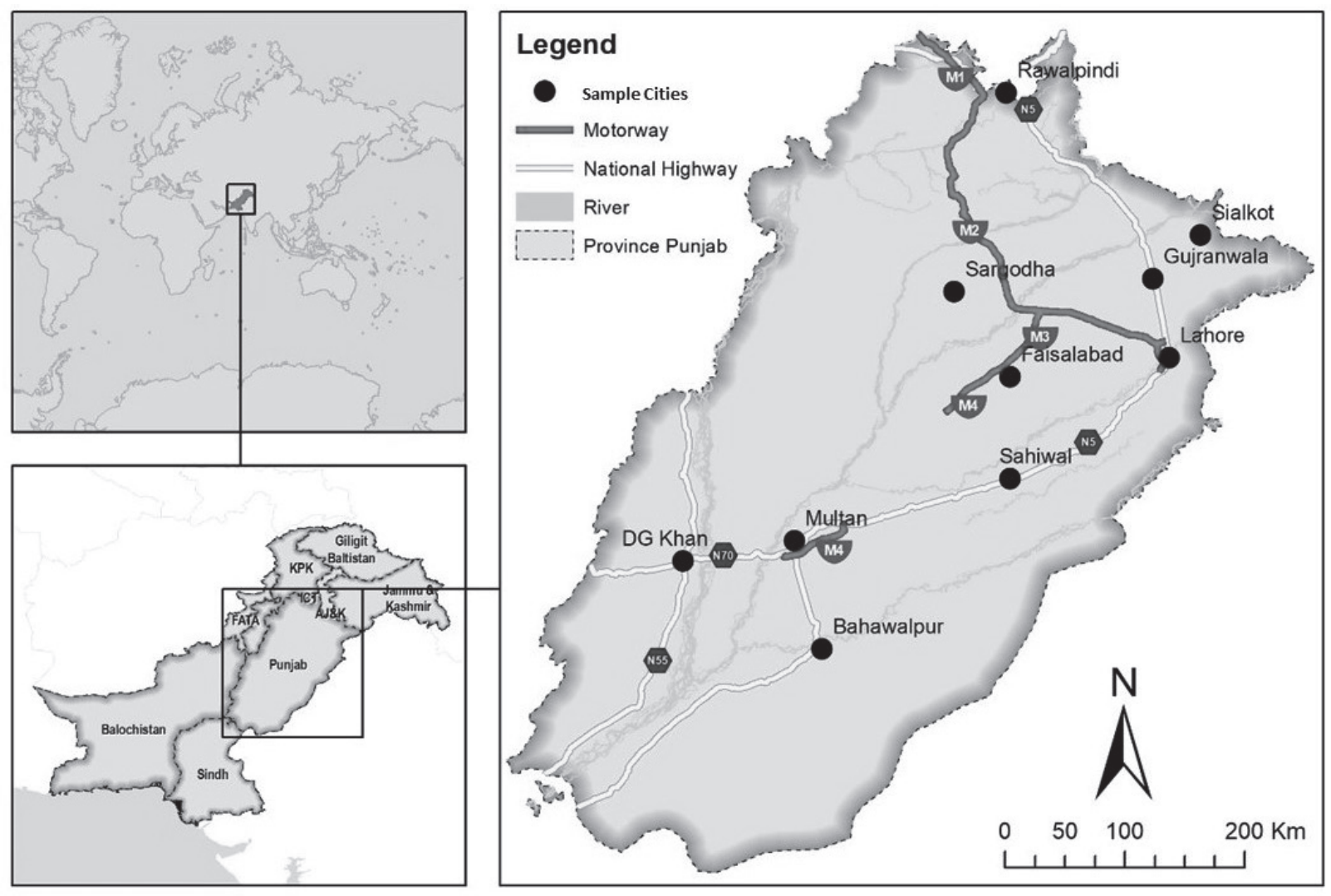

Fig. 1 Map of the study area.

a $10 \mathrm{~km}$ buffer on the city boundary as cities' expansion above the buffer was not observed through multitemporal satellite images. The sub-setting minimized the file size and provided accuracy in classification as only the histogram of the Area of Interest (AOI) was available for spectral classification.

\section{Urban Expansion and Saturation}

The built-up areas were extracted by classifying satellite images using the Maximum Likelihood
Classifier (MLC) [34]. The MLC algorithm identified the neighborhood pixel of the same intensity in the raster data set and spectral rules defined the classified layer [35]. Fig. 2 shows the maximum likelihood of cluster samples. MLC estimates expotential models fordependent data by using Markov model's [36]. It is generally used for classifier evaluation as a reference, thus making the Gaussian probability density function model an optimal classifier [37]. To demarcate areas of contiguous urban development, the built-up pixels were categorized as urban by applying an iterative

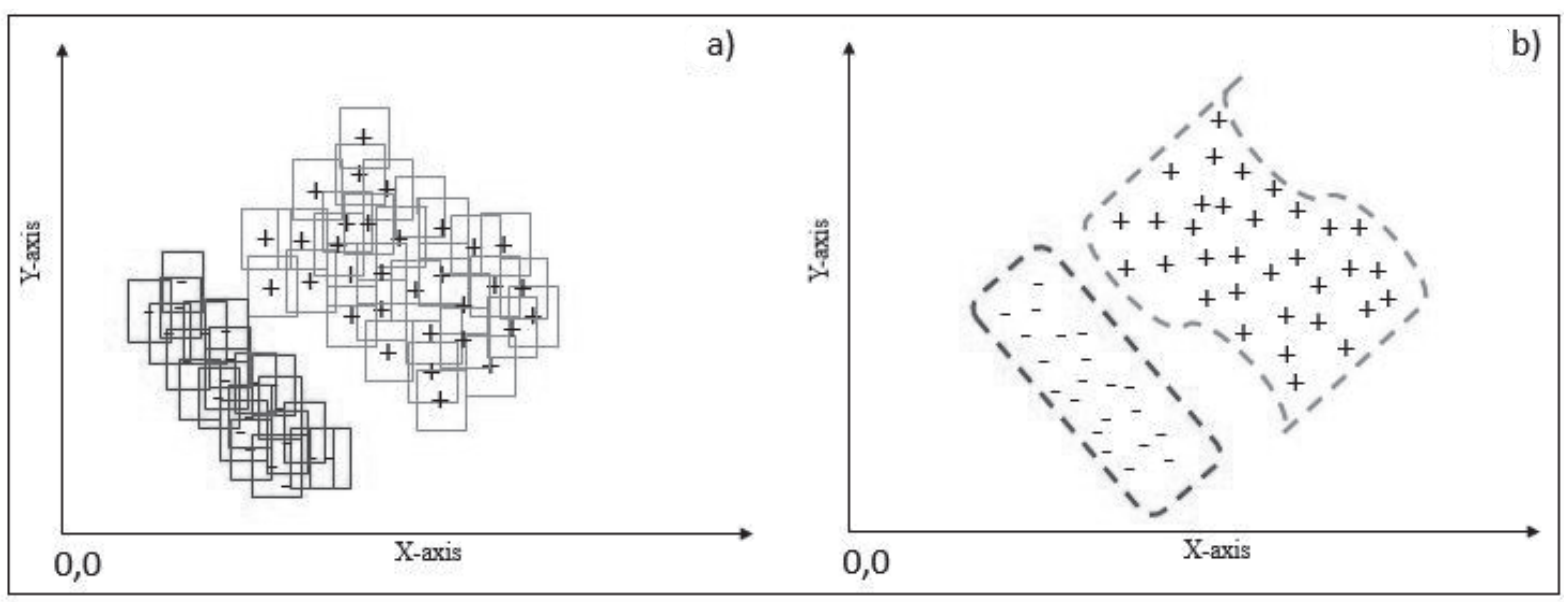

Fig. 2. Maximum Likelihood Clustering. 


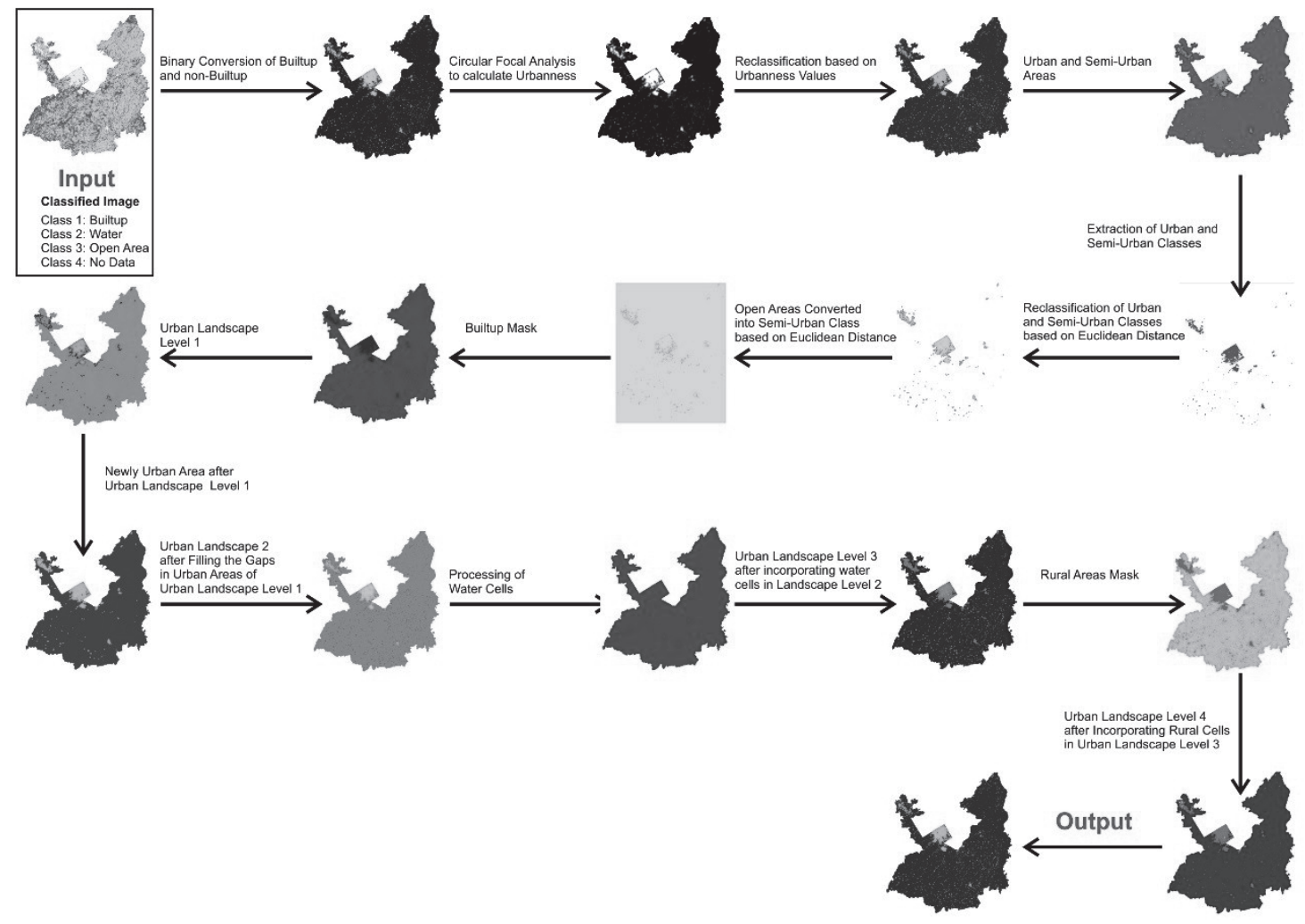

Fig. 3. Raster workflow - Cellular Automata Approach.

python-based algorithm. The developed algorithm was influenced by the methodology defined by Lincoln Institute of Land Policy, United Nations Habitat, and the New York University (NYU) urbanization project [38]. The algorithm incorporated built-up pixels within the ten min walking distance circle of $1 \mathrm{~km}^{2}$ area and $584 \mathrm{~m}$ radius. Urban pixels with the majority of continuous built-up pixels within the walking distance circle were marked as the functional boundary of the city. The built-up pixels having $10-50 \%$ of the built-up within their walking distance were categorized as suburban. The respective urban extents defined functional city boundaries. The workflow of urban extents that were manually refined to address anomalies in the local context shown in Fig. 3. The figure elaborate raster flow of cellular automation of exraction of the built up area of Area of Interest. Urban saturation was calculated based on built-up area pixels and urban extent, where the urban extent was used as the denominator [39].

The final built-up area extracted from the Landsat satellite images after using cellular automata method was converted into binary language and assigned the value of " 1 " while all other classes were assigned " 0 " as well it also define as the builtup and non builtup area. The majority of the continuous built-up pixels were classified as the main city. Focal analysis was performed for the neighborhood value assignment of each pixel [35]. Euclidean distance analysis was performed to fill the open spaces and the raster data were reclassified into two types: Urban and Suburban.
Python-based script for cellular automation derived the urban footprint by incorporating urban mask, water cell, and rural area mask was used.

\section{Population Density}

The dasymetric concept was used for the division of administrative area into multiple spatial units such as population data sets clusters similarly the dasymetric concept also established to assess the fine resolution population distribution in an area where census data was coarsely available [40]. Thus, the LandScan global model (developed based on ancillary datasets, i.e., land cover, settlement location, slope, and proximity to roads) was used to measure the population distribution as discussed in formula 1. Fig. 4 shows population distribution of the study area; the population unit and raster cell area are overlapped with spatial weight for block-wise population distribution. Small area estimation (SAE) with respect to landscan used to produce estimates of population counts for small areas, and accuracy assessment of estimations [41]. Considering data gaps of population census in Pakistan, the urban population of ten cities was measured by using projected Landscan data, which is the community standard for global and regional population distribution [42]. The database uses subnational level census counts for each country; integrate it with spatial and imagery analysis (land cover, roads, slope, urban areas, and village locations) using a multivariable modelling approach to disaggregate census 
counts. LandScan characterizes an ambient population of the cells in integer population counts, representing an average within an administrative boundary. Once the pixel grid was converted to the area grid, the number of persons in each cell was divided by the surface area of the cell, which provided the population density as shown in Fig. 4.

The pixel size of the LandScan ${ }^{\mathrm{TM}}$ data is $1 \mathrm{~km}$ (30" x 30") and it provides sufficient information while estimating data of large cities. Following formula [41] is used to estimate the density of study area.

$$
\mathrm{P}_{\text {op }} \text { Density }=\left(1 * \mathrm{a}_{\mathrm{s}}\right)^{2} * \operatorname{Cos}_{\mathrm{L}} / \mathrm{P}_{\text {op }} \text { cell }
$$

...where as:

$\mathrm{P}_{\text {op }}$ Density $=$ Population density of particular cell,

$1=$ Length of one arc degree at the equation,

$\mathrm{a}_{\mathrm{s}}=30$ arc-sec in decimal degree and $\operatorname{Cos}_{\mathrm{L}}=$ Cosine of latitude.

The demographical data were redistributed across each grid cell for taking the population densities as weights across the entire region [43]. This includes projection and manual verification to improve the precision of population distribution across the ten large cities of Punjab. The multi-source geographical factors such as, population distribution, topography, settlements, traffic network and road network were the core factors used in LandScan [43] and represent a fusion model to stimulate the distribution of population. Urban extent change affects the functions, structures, and surface land use, which in turn influences the variability of eco-system and improvement of human being [44-46].

\section{Cellular Automata}

Satellite data of 10 years of equal intervals along with population density, topography and slope, road network distances are used in this study to analyse the cities growth $[47,48]$. The satellite based urban extent during 2008-2017 was cloned by the stimulated approach of principal component analysis and cellular automata to identify the similarity during classification $[49,50]$.

\section{Results and Discussion}

\section{Urban Expansion}

The study revealed the temporal growth rate of contiguous urban extents from 2008 and 2018 as 6\% per year. In Fig. 5 urban extent of large cities were presented. The urban areas of these ten citiesincreased from $914 \mathrm{~km}^{2}$ in 2008 to $1649 \mathrm{~km}^{2}$ in 2018 . Angel et al, [51] analyzed the urban sprawl and its patterns as well as changes over the time. They take sprawl to be relative than an urban landscape absolute characterization. Moreover, Galster et al, [52] define and measure the urban landuse and spatial configuration pattern of cities area. They observed the spatial change of cities over the observed time period. Fig. 6 shows the increase in urban spwral of the ten cities with the annual growth rates.

Fig. 6 shows the annual growth rates of the ten large cities in Punjab; Rawalpindi is physically growing at a rate of $8.2 \%$ and is expected to be the second-largest city by 2040 following Lahore, which is the biggest city in the province. Lahore's growth has developed mostly in south and southeast directions and the area towards west and north has constituted a physical barrier in those directions. Minallah et al, [53] observed that the population of Gujranwala increased in the observed time period due to migration trend toward Gujranwala. The urban built-up areas of Lahore has been reached its double from 1999 to 2011 as well its increasing pressure on the administration of city [54]. Although, the physical growth of Lahore is expected to be along the major roads including, Multan Road, G.T road, Ferozpur road, and Raiwind road. The next largest city will be Gujranwala with $8.1 \%$ annual area growth rate in terms of morphology. With the current growth patterns, Gujranwala intends to become larger than Faisalabad, even to grow as big as today's Faisalabad.
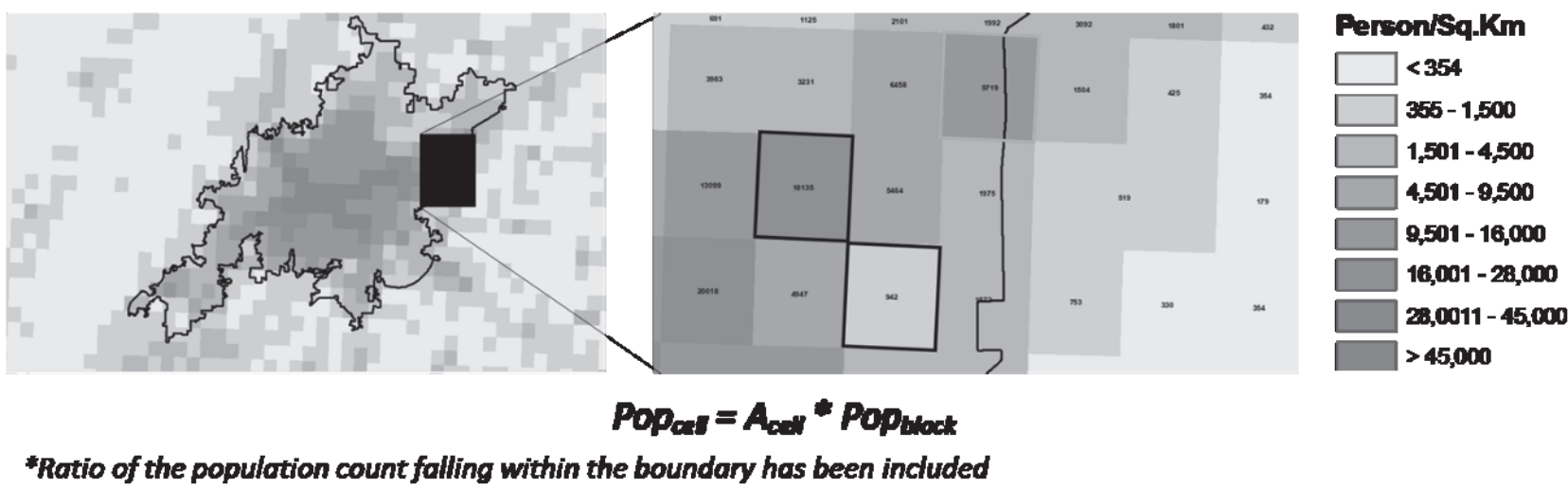

*Ratio of the populotion count falling within the boundary has been included

Fig. 4. Population calculation against each raster grid cell. 


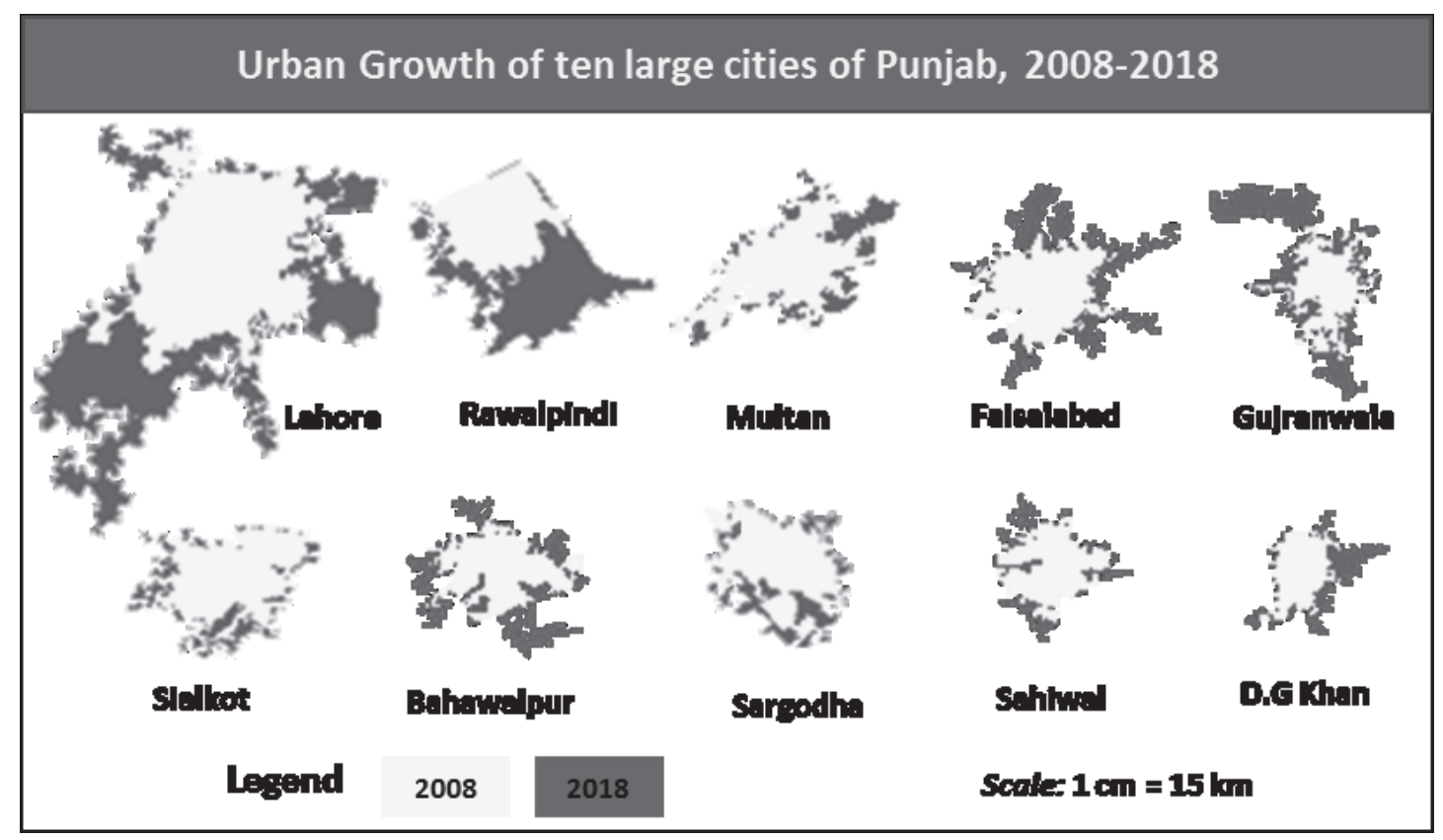

Fig. 5. The urban extent of the ten large cities in Punjab.

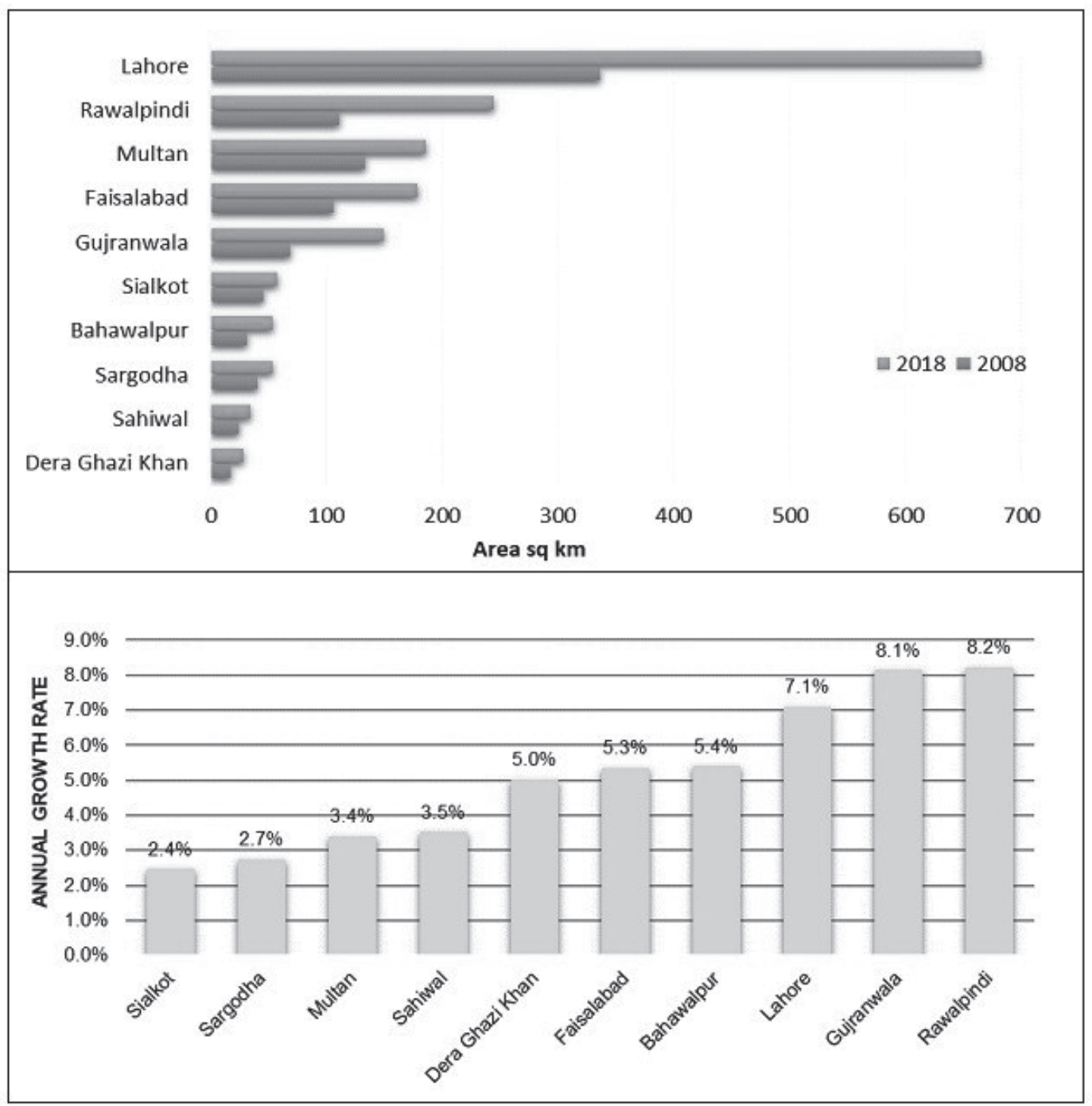

Fig. 6. Urban sprawl in $\mathrm{km}^{2}$ and growth rate of the ten large cities in Punjab. 


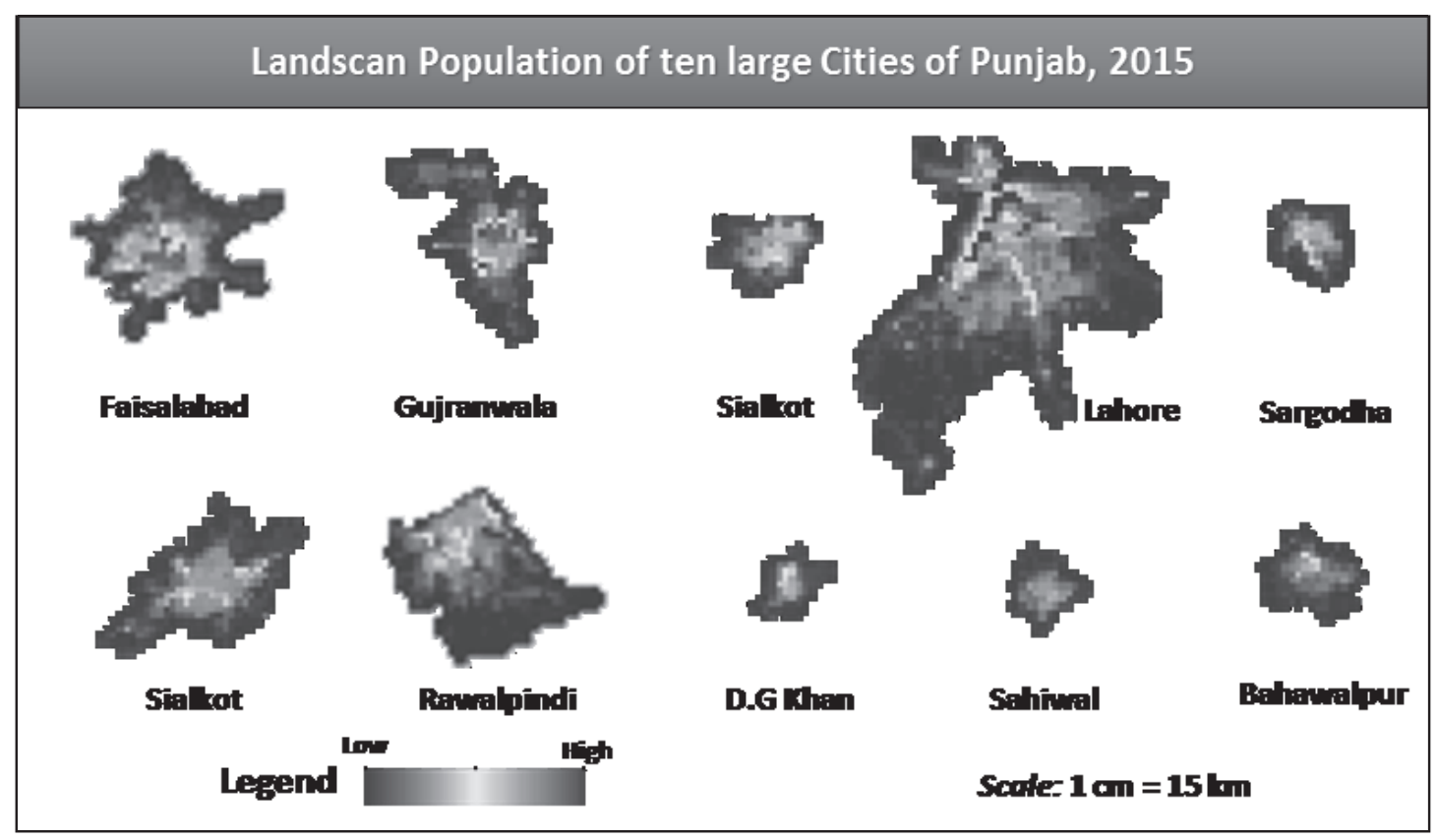

Fig. 7. LandScan population of the ten large cities in Punjab for the year 2018.
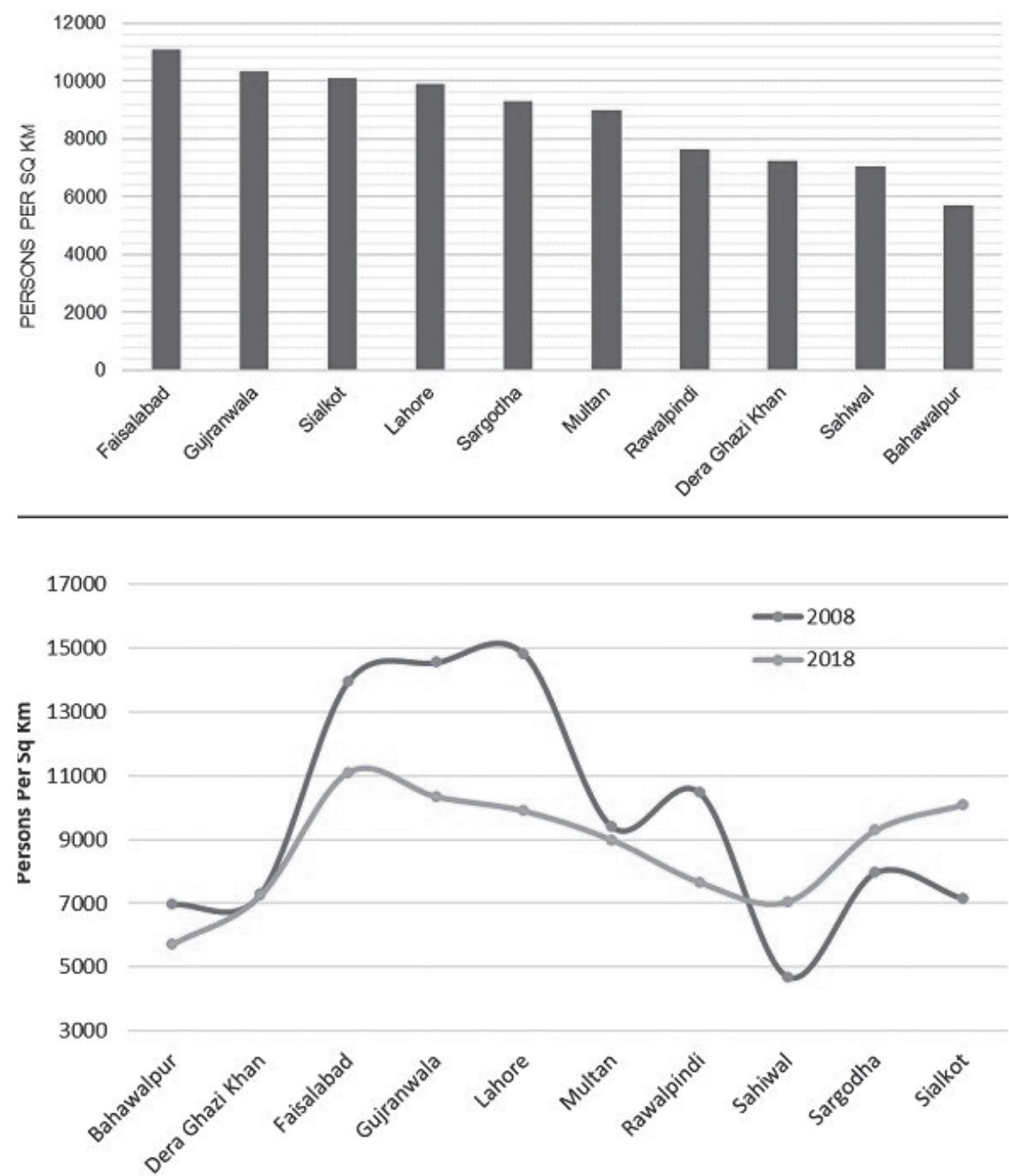

Fig. 8. Population density with ranking of the ten cities. 
The satellite images and data analytics showed minimal spatial growth in the past decade i.e. Sialkot $(2.4 \%)$ and Sargodha (2.7\%).

\section{Population Densities}

Population density is an interesting criterion to measure city crowdedness (Fig. 7). Most urban settlements in Punjab expanded because of the transformation from agricultural land to urban/periurban areas [55]. The increase in urban densities directly affect the transport system and other need as Cervero and Guerra [56] investigate the relationship between transit and urban density in United States and conclude that the increase in urban density would cause increase in ridership on rail system. Akbar et al, [57] analyzed the spatial and temporal trends of LULC from 1988 to 2016 and observed the population growth had been increased also the population of Lahore was $168 \mathrm{~km}^{2}$ and it will be reached up to $625.16 \mathrm{~km}^{2}$ by 2040. Fig. 8 shows the population density of the ten cities selected in this study and provides an additional perspective on population density change over time. The analysis revealed Faisalabad as the most crowded city $\left(179 \mathrm{~km}^{2}\right)$ with a population of $3,164,704$ people, and has an average density of almost 11,092 people per $\mathrm{km}^{2}$. Meanwhile, Bahawalpur is the least densely populated city, with 5,715 people per $\mathrm{km}^{2}$. Sahiwal and Dera Ghazi Khan come close to the position of the second least populated city, with almost 7000 people per $\mathrm{km}^{2}$. Lahore, Gujranwala, and Faisalabad had high densities in 2008 but showed a decrease in the densities in 2018, mainly due to the unregulated growth and fragmented development of new housing schemes in the peripheries of these cities. This research results showing that if the density-wise composition of the city projects that if the current pattern of decreasing densities and unplanned sprawl continues, the city area will have low population densities by 2050 .

\section{Urban Saturation}

We found that the saturation levels of Lahore, Multan, Rawalpindi, Bahawalpur, and Sargodha have decreased over the last decade. The urban saturation level with infill development showed in Fig. 9. In Gujranwala, infill and sprawl found to be equally increasing as per the data analysis. Faisalabad, Dera Ghazi Khan, Sahiwal, and Sialkot indicated high saturation levels of the built-up spread. For sustainable growth of the cities, the saturation level of the city must be increased by developing vacant areas within the administrative extent of the city before sprawling further outwards. Moreover, vertical growth shall also be promoted. The spatial portrait of the urban saturation level is shown in Fig. 10.

\section{Accuracy Assessment}

The overall accuracy was found to be $92.45 \%$ for the 2008 urban sprawl and it was $97.21 \%$ for 2018 respectively. The six classes obtained includes water bodies, built up, barren land, bare soil, agriculture and other vegetation for 2008 and 2018. User accuracy and the producer accuracy were calculated based on actual map locations and obtain (map locations). For 2008, user accuracy for each class i.e. water bodies $99.55 \%$, built up $86.24 \%, 81.25 \%$ for barren land, $76.01 \%$ for bare soil, $81.34 \%$ for agriculture and $88.23 \%$ for other vegetation. The producer accuracy calculated as $99.67 \%, 84.18 \%$, $82.67 \%, 78.54 \%, 84.32 \%$, and $81.01 \%$ for water bodies, built-up, barren land, bare soil, agriculture land and vegetation for the year 2008. For 2018, the user accuracy identified the percentages as $99.82 \%$ for water bodies, built-up as $88.24 \%$, barren land as $84.51 \%$, bare soil as $86.44 \%, 88.21 \%$ as agriculture land, and vegetation as $92.54 \%$. The producer accuracy was detected as good as expected and observed that produced map were relatively matched with the ground-truthing location which is found to be exactly as of ground reality.

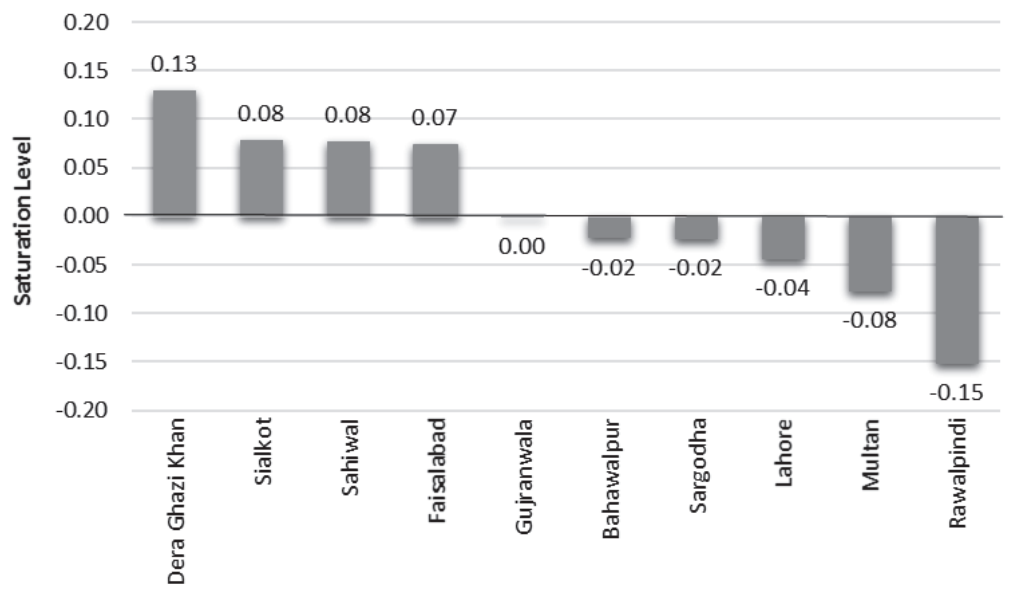

Fig. 9. Urban Saturation - Infill development. 
The producer accuracy for the water bodies were $99.82 \%, 89.36 \%, 85.43 \%, 86.84 \%, 87.92 \%, 84.65 \%$ for built-up, barren land, bare soil, agricultural land and vegetation. The Kappa statistics were $0.90 \%$ and
$0.95 \%$ for 2008 and 2018 which is good as per kappa standardized values. The obtained accuracy was better as compared to the other accuracies used in other studies related to cellular automata model [58].
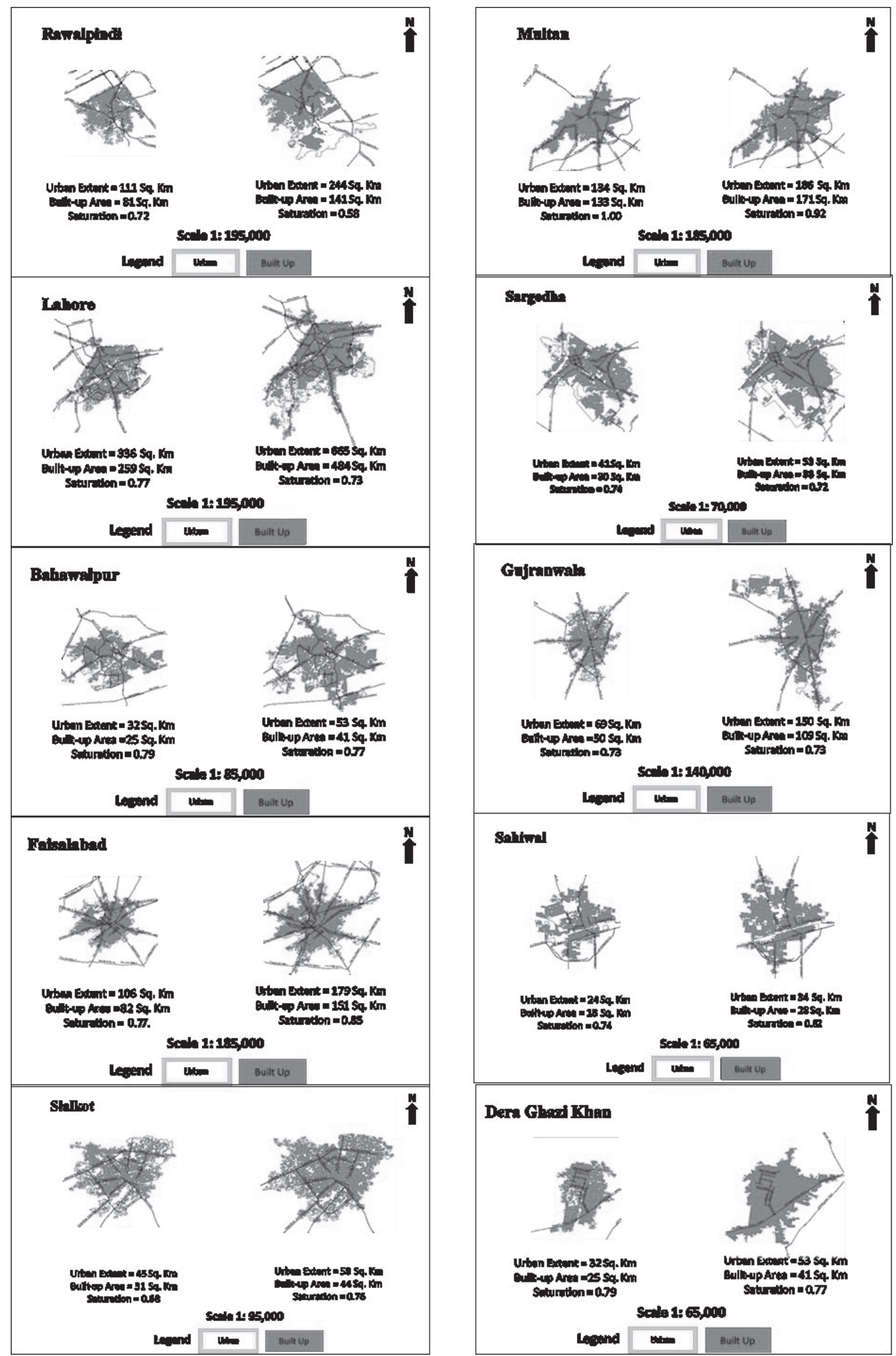

Fig. 10. Urban saturation spatial representation. 


\section{Conclusions}

This study provided an insight into two important factors of urban dynamics i.e., land use and population. From 2008-2018 the total urban land area increased from $943 \mathrm{~km}^{2}$ to $1649 \mathrm{~km}^{2}$ with an annual growth rate of $6 \%$ and the population of the cities increased from 15.5 to $20.1 \mathrm{M}$ with an annual growth rate of $3 \%$. If the urban land area continues to grow at a similar rate, an expansion of $100 \%$ is estimated by 2050 . The data and maps witnessed new development in the outer peripheries of the cities resulting in horizontal expansion instead of compact development. The continuity and infill patterns mark the sustainable development of cities and hold potential for land use planning and urban management strategies across different scales. It is important to focus on ways to increase the population density through vertical as opposed to horizontal development, by developing vacant areas within the administrative extents of the cities before sprawling further outwards. The government should focus on developing rules and defining policies to ensure the transformation of these urban areas into compact cities. The vertical growth can also reduce the outer development and operational cost while minimizing the unplanned urbanization pressure on the peripheral land.

\section{Acknowledgements}

We would like to thanks the USGS and OAK Ridge National Laboratory for providing satellite imagery and population dataset for analysis. We are also grateful to the Urban Unit for the support and guidance throughout this study.

\section{Conflict of Interest}

The authors declare no conflict of interest.

\section{References}

1. FRANCIS R. Finding Top Gear Urban Centers as Engines of Growth. Saskatchewan Business Magazine, 2016.

2. COLENBRANDER S. Cities as engines of economic growth: The case for providing basic infrastructure and services in urban areas. Produced by Human Settlements Group, 2016.

3. BONGAARTS J. Human population growth and the demographic transition. Philosophical Transactions of the Royal Society of London Biological Sciences. 2009 Oct 27, 364 (1532), 2985, 2009.

4. YANG X., YE T., ZHAO N., CHEN Q., YUE W., QI J., ZENG B., JIA P. Population mapping with multisensor remote sensing images and point-of-interest data, Spatial demography and health (ISLES) remote sensing, 11 (5), 574, 2019.

5. YAMAGATA Y., BAGAN H. Analysis of urban growth and estimating population density using satellite images of nighttime lights and land-use and population data, GIScience and remote sensing, 52 (6), 765, 2015.

6. SUDHIRA HS., RAMACHANDRA T.V., JAGADISH KS. Urban sprawl: metrics, dynamics and modelling using GIS, International Journal of Applied Earth Observation and Geoinformation, 5 (1), 29, 2004.

7. SIEDENTOP S., FINA S. Monitoring urban sprawl in Germany: towards a GIS-based measurement and assessment approach, Journal of Land Use Science, 5 (2), 73, 2010.

8. WAKHARIYA J., GANGRADE P., MANEKAR A. Mahaganana: An Approach to a Smart Census in India, In 2019 International Conference on Innovative Trends and Advances in Engineering and Technology (ICITAET), 166-169 IEEE, 2019.

9. United Nations. Department of Economic and Social Affairs, Population Division. World Urbanization Prospects: The 2014 Revision, Highlights. (ST/ESA/ SER.A/352), 2014.

10. PBS, Pakistan Bureau of Statistics. http://www.pbs.gov.pk/ content/population-census. Accessed year 2018.

11. ARSANJANI J.J., KAINZ W., MOUSIVAND A.J. Tracking dynamic land-use change using spatially explicit Markov Chain based on cellular automata: the case of Tehran. International Journal of Image and Data Fusion, 2 (4), 329, 2011.

12. WANG R., MURAYAMA Y. Change of land use/land cover in Tianjin City based on the markov and cellular automata models. International Journal of Geo-information ISPRS Int. J. Geo-Inf. 6 (5), 150, 2017.

13. LI M., ZANG S., WU C., NA X. Spatial and temporal variation of the urban impervious surface and its driving forces in the central city of Harbin. Journal of Geographical Sciences. 28, 323, 2018.

14. DENG C., WU C. Imporving small area population estimation: An integrated geographic and demographic approach. Ann. Asso. Ameri. Geographers 103 (5), 1123, 2013.

15. HILLSON R., COATES A., ALEJANDRE J., JACOBSEN K., ANSUMANA R., BOCKARIE A., BANGURA U., LAMIN J., STENGER D. Estimating the size of urban populations using Landsat images: a case study of Bo, Sierra Leone, West Africa. Int. Jour. Health Geo. 18, 16, 2019

16. COMBER A., ZENG W. Spatial interpolation using aerial features: A review of methods and opportunities using new forms of data with coded illustrations. Geography Compass 13 (10), 2019.

17. BALAKRISHNAN K. A method for urban population density prediction at $30 \mathrm{~m}$ resolution. Cartography and Geographical Information System 47 (3), 2019.

18. DEBNATH R., NURUL-AMIN A.T.M. A geographic information system-based logical urban growth model for prediction spatial growth of an urban area, 43 (3), 2016.

19. SAMAK Y., ALHARITH A. Fighting terrorism more effectively with the aid of GIS: Kingdom of Saudi Arabia Case Study. American Jour. of Geographical Information System, 7 (1), 15, 2018.

20. BHADURI B., BRIGHT E., COLEMAN P., DOBSON J. Land Scan. Geoinformatics, 5 (2), 34, 2002.

21. United Nations. Department of Economic and Social Affairs, Population Division. Demographic Yearbook, 2015.

22. Government of Pakistan. Hand Book of Populations Census Data. Population Census Organization, Statistics Division Government of Pakistan, 1998-2017. 
23. BHATTI S.S., TRIPATHI N.K., NITIVATTANANON V., RANA I.A., MOZUMDER C. A multi-scale modeling approach for simulating urbanization in a metropolitan region. Habitat International. 50, 354, 2015.

24. KHAN A.A., ARSHAD S., MOHSIN M. Population growth and its impact on urban expansion: A case study of Bahawalpur, Pakistan. Universal Journal of Geoscience, 2 (8), 229, 2014.

25. MCKEE J., ROSE A., BRIGHT E., HUYNH T., BHADURI B. Locally adaptive, spatially explicit projection of US population for 2030 and 2050. Proceedings Of The National Academy Of Sciences, 112 (5), 1344, 2015.

26. CALKA B., BIELECKA E. Reliability Analysis of LandScan Gridded Population Data. The Case Study of Poland. ISPRS International Journal of Geo-Information. 8 (5), 222, 2019.

27. LI X., ZHOU Y., ZHU Z., LIANG L., YU B., CAO W. Mapping annual urban dynamics (1985-2015) using time series of Landsat data. Remote Sensing of Environment. 216, 674, 2018.

28. KUMAR A., TRIPATHY P. Monitoring and modelling spatio-temporal urban growth of Delhi using Cellular Automata and geoinformatics. Jour. Cities. 19, 52, 2019.

29. SAKLANI A., DEEP S. Urban sprawl modeling using cellular automata. Egypt. Jour. Remote sensing and space science. 17 (2), 2014.

30. ORNL, Oak Ridge National Lab. LandScan HighResolution Global Population Data Set. https://landscan. ornl.gov/

31. USGS, United State Geological Survey. https:// earthexplorer.usgs.gov/, Accessed year 2018.

32. SCHROEDER TA., COHEN WB., SONG C., CANTY M.J., YANG Z. Radiometric correction of multi-temporal Landsat data for characterization of early successional forest patterns in western Oregon. Remote sensing of environment, 103 (1), 16, 2006.

33. CARVALHO O., GUIMARAES R., SILVA N., GILLESPIE ASCN., GOMES TAR., SILVA CRISTIANO R., CARVALHO D.F., Radiometric Normalization of temporal images combining automatic detection of Pseudo-Invariant features from the distance and similarity spectral measures, Density scatterplot analysis, and robust regression. Remote Sens. 5 (6), 2763, 2013.

34. RAZA D., KARIM RB., NASIR A., KHAN S.U., ZUBAIR MH., AMIR R. Satellite Based Surveillance of LULC with Deliberation on Urban Land Surface Temperature and Precipitation Pattern Changes of Karachi Pakistan. J Geogr Nat Disast, 9 (237), 2167, 2019.

35. BOLSTAD P., LILLESAND T.M. Rapid maximum likelihood classification. Photogrammetric Engineering and Remote Sensing, 57 (1), 67, 1991.

36. GEYER C.J., THOMPSON E.A. Constrained Monte Carlo maximum likelihood for dependent data. Journal of the Royal Statistical Society: Series B (Methodological), 54 (3), 657, 1992.

37. PAALANEN P., KAMARAINEN J.K., ILONEN J., KÄLVIÄINEN H. Feature representation and discrimination based on Gaussian mixture model probability densities - practices and algorithms. Pattern Recognition, 39 (7), 1346, 2006.

38. ANGEL S., PARENT J., CIVCO D.L., BLEI A.M. Atlas of urban expansion Cambridge, MA: Lincoln Institute of Land Policy, 397, 2012.

39. GOLDBLATT R., STUHLMACHER M.F., TELLMAN B., CLINTON N., HANSON G., GEORGESCU M., BALLING JR R.C. Using Landsat and nighttime lights for supervised pixel-based image classification of urban land cover. Remote Sensing of Environment, 205, 253, 2018.

40. ROSE A.N., BRIGHT E.A. The LandScan Global Population Distribution Project: current state of the art and prospective innovation. Oak Ridge National Lab. (ORNL), Oak Ridge, TN (United States), 2014.

41. ANDERSON W., GUIKEMA S., ZAITCHIK B., PAN W. Methods for Estimating Population Density in DataLimited Areas: Evaluating Regression and Tree-Based Models in Peru. PLoS ONE. 9 (7), 2014.

42. LLOYD C.T., CHAMBERLAIN H., KERR D. Global spatio-temporally harmonised datasets for producing highresolution gridded population distribution datasets. Big Earth Data. 3 (2), 108, 2019.

43. BAI Z., WANG J., WANG M., GAO M., SUN J. Accuracy Assessment of Multi-Source Gridded Population Distribution Datasets in China. Sustainability 10, 1363, 2018.

44. GAGLIO M., ASCHONITIS V.G., GISSI E., CASTALDELLI G., FANO E.A., Land use change effects on ecosystem services of river delats and coastal wetlands: A case study in Volano River Delta, Italy. Wetland Ecol. Manage. 25 (1), 67, 2017.

45. NELSON E., POLASKY S., PENNIGTON B., JOHNSON K.B. The impact of land-use change on ecosystem services, returns to landowners and biodiversity: A case study of Minnesota. Environment Resourc. Econ. 48 (2), 219, 2011.

46. ECHEVERRIA C., OYARZUN C., RODRIGUEZ E., MORALES The impact of land-use change on eco-system services and biodiversity in the Chilean forests. Landscape Ecology. 1, 5982, 2018.

47. BALZTER H., BRAUN P., KOHLER W. Cellular automata models for vegetation dynamics. Ecology Model. 107, 113, 2017.

48. BLCCIC I., PRASTACOS P., TRUNFIO G.A., VERIGOS E. Modelling urban dynamics with cellular automata: A model of the city of Heraclion. Conf. on GIS. 2014.

49. MOGHADAM S., HELBEH M. Spatiotemporal urbanization processes in the megacity of Mumbai India, A case Markov chain-cellular automata urban growth model, 40, 140, 2013.

50. ARSANJNI J., HELBICH M., KAINZ M., BOLOORANI D. Integration of logistic regression, Markov chain and cellular automata models to simulate urban expansion. Int. J.Appl. Earth Observations Geoinfor. 21, 265, 2013.

51. ANGEL SHLOMO., JASON PARENT., DANIEL CIVCO Urban sprawl metrics: an analysis of global urban expansion using GIS, Proceedings of ASPRS 2007 Annual Conference, Tampa, Florida May, 7 (11). Citeseer, 2007.

52. GALSTER GR., HANSON H., WOLMAN S., COLEMAN J. Freihage, Wrestling Sprawl to the Ground: Defining and Measuring an Elusive Concept, Housing Policy Debate 12 (4), 681, 2001.

53. MINALLAH M.N., GHAFFAR A., RAFIQUE M., MOHSIN M. Urban growth and socio-economic development in Gujranwala, Pakistan: a geographical analysis. Pakistan Journal of Science, 68 (2), 176, 2016.

54. RANA I.A., BHATTI S.S. Lahore, Pakistan-Urbanization challenges and opportunities. Cities, 72, 348, 2018.

55. KHAN S.U., RAZA D., SAEED U., YOUNAS I., ARSHAD M., ALI M., AHMAD S.R. Evaluation of Foliage Spread Conversion into Industrial Land Under the Significance of Urbanization and Environment. Fresenius Environmental Bulletin, 29 (6), 4612, 2020. 
56. CERVERO R., GUERRA E. Urban densities and transit: A multi-dimensional perspective, 2011.

57. AKBAR T.A., HASSAN Q.K., ISHAQ S., BATOOL M., BUTT HJ., JABBAR H. Investigative spatial distribution and modelling of existing and future urban land changes and its impact on urbanization and economy. Remote Sensing, 11 (2), 105, 2019.
58. KAMUSOKO C., ANIYA M., ADI B., MANJORO M. Rural sustainability under threat in Zimbabwe - simulation of future land use/cover changes in the Bindura district based on the Markov-cellular automata model. Applied Geography, 29 (3), 435, 2009.

\title{
Supplementary Material
}

\author{
Iterative Python Based Script \\ WTO import the Arcmap library \\ import arcpy \\ "To grant the overwrite permission \\ arcpy.env. overwriteoutput $=1$ \\ "To check the extension required for further processes \\ arcpy.CheckoutExtension ("Spatial") \\ "Input file will be given here \\ input $=$ arcpy.GetParameterAsText (e) \\ \#TO get the raster properties, i.e. cell size \\ cellsize $=$ float (arcpy.GetRasterProperties_management (input, "CELLSIZEX").getoutput(e)) \\ "To create a file from the input. In output, 1 represents the builtup and the rest is non-builtup \\ builtup $=\operatorname{arcpy.sa.EqualTo(input,3)}$ \\ \#To create a neighnpurhood circle in map units \\ Nbrcircle $=$ arcpy.sa.NbrCircle(564, "MAP") \\ \#The neighbourhood circle was applied on the builtup created in previous \\ \#step to perform focal analysis. The output represents the urbanness ranging \\ \#from 0 to 1,1 for urban area and $e$ for the other \\ urbanness = arcpy.sa.Focalstatistics(builtup, NbrCircle, "MEAN", "DATA") \\ \#To determine the builtup classes, reclassify the urbanness map and then multiplied with builtup \\ builtup_classes = arcpy.sa.Reclassify (urbanness, "Value", remap, "NODATA") * builtup \\ \#To get the required values, the above output is filtered. Urban suburban areas have been \\ \#determined based on the values of previous output. 1 represents urban and $e$ non urban. \\ urb_suburb $=$ arcpy.sa. Test (builtup_classes, "value $=1$ or value $=2^{\prime \prime}$ ) \\ we require just builtup cells, so non-builtup cell were given nulled value \\ urb_suburb_1_null = arcpy.sa.setNull (urb_suburb, 1 , "value $=\theta^{\prime \prime}$ ) \\ \#TO calculate the Euclidean Distance in a distance of $10 e m$ from each cell \\ builtup dist $=$ arCDy.sa.EuCDistance (urb suburb 1 null, 100 )
}

